\title{
Impact of CEO Image on the Consumer Trust in the Organization
}

\author{
Jurgita Stravinskiene, Rimante Hopeniene, Indre Levickyte
}

\author{
Kaunas University of Technology \\ K.Donelaicio st. 73, LT-44029, Kaunas, Lithuania \\ E-mail.jurgita.stravinskiene@ktu.lt; rimante.hopeniene@ktu.lt; levickyte.indre@gmail.com \\ cross $^{\text {ref }}$ http://dx.doi.org/10.5755/j01.ee.31.2.24208
}

\begin{abstract}
Corporate image entails several elements of which the image of Chief Executive Officers (CEOs) is regarded as one of the most significant in building the consumer opinion about the organisation. The study of academic literature has shown that the role of a leader, the impact of management styles for the achievements of the organisation are investigated quite extensively by researchers of leadership, psychology or sociology. However, from the prospect of marketing, the effect of CEO image and its elements on consumer behaviour and establishment of long-term relationships has not been analysed. The aim of the paper was to evaluate an impact of CEO image and its elements on consumer trust in the organisation. The empirical data was collected from 186 respondents who are potential consumers of successful Lithuanian business companies. The survey has showed that the psychological traits and verbal/non-verbal behaviour of the CEOs have the highest impact, and the leadership has the lowest impact on consumer trust on the organisation. The impact on the consumer trust with organisation varies and depends on the assessment of the overall image of CEOs, i.e. the CEO image has the most influence when the consumers are neutral about the overall image of the CEO and the lowest influence when the CEO is evaluated negatively.
\end{abstract}

Keywords: CEO Image; Organisational Image; Consumer Trust; Long-Term Relationship; Public Relations.

\section{Introduction}

The positively formed corporate image leads to an excellent reputation, which guarantees more stable income, easier survival of crises, consumer willingness to pay more for goods or services, the greater motivation of the organisation's employees, and even the growth of the corporate value. With increasing competition and the growing influence of public opinion on the attitude of consumers towards organisations and their products, the building of CEO image becomes a rather relevant area of research (Park, Berger, 2004). It is particularly important for a specialist of public relations or marketing who creates the corporate image to understand the role of CEO image to relationship with internal and external stakeholders (Park \& Berger, 2004; Lievens \& Slaughter, 2016).

Public relation studies quite reasonably demonstrate the importance of research on CEO image, the corporate image and interaction of concepts of consumer behaviour. Scientists have found that the corporate image has an impact on consumer intentions (Nguyen \& Leblac, 2001; Keh \& Xie, 2009; Lin \& Lu, 2010), consumer's loyalty (de Leniz, del Bosque Rodriguez, 2016), consumer's satisfaction (Helm et al., 2010), and value perceived by consumers (Zameer et al., 2015). Researchers who analyse the corporate image-forming model distinguish three groups of factors helping to create the preferred corporate image. Park and Berger (2004), Zameer et al. (2015) note that the behaviour group factors of the corporate image reveal the behaviour that determines the management in the organisation and its employees, the role of the employer and the reputation of CEOs. The reviewed research suggests that CEOs and their behaviour affect the corporate image, but so far, the research on the issues of CEO image and consumer trust with the organisation is missing.
With the changing societal attitudes and the increasing importance of the organisation as the employer's image, the discussion about the image of CEOs becomes relevant for the understanding how much the image component plays an important role in building long-term relationships with consumers and what the influence of CEO's image on consumer confidence with the organisation is.

According to Valieva et al. (2016), specifically shapedCEO image can save a lot of effort and time in addressing problems related to corporate management and significantly contribute to the corporate image in society. Antonakis and Day (2017) note that a number of scholars have attempted to identify and explain what CEO should be, and what traits he/she needs to have. Regardless of the research in the field of psychology, leadership or management sciences, the effect of the CEO's image on the peculiarities of consumer behaviour has not been studied yet.

This led to the fact that many empirical studies were targeting the search for the character traits of CEO as a leader, effect on the management style on the employee behaviour within the organisation, corporate achievements, and have disclosed the influence of CEO's image on consumer confidence only fragmentary (Park \& Berger, 2004; Boyd \& Solarino, 2016). Fulmer, Gelfand (2012) conducted a trust analysis between the different levels of the organisation, and found that the prevalence of trust at various levels of the organisation yield undoubtedly better results and encourage positive consumer behaviour. When consumers trust the organisation, they have a stronger tendency to buy products and services of the organisation (Lin et al., 2011), feel more satisfaction, are more often involved in the product development process, and trust in the organisation more effectively mitigates the risk incurred by the consumer (Dovaliene et al., 2007). Keh, Xie (2009) emphasize that the 
consumer future intentions depend on the strength of the relationship quality. The more trusted organisation is, the more likely consumers are to continue to collaborate with the organisation. If the relationship is particularly close, consumers feel committed to the organisation and tend to pay even a higher price for goods and services. Gozukara and Yildirim (2015) have found that trust has a significant impact on the reputation of the organisation, and trust and commitment have the potential to contribute to the successful development of relationship marketing.

Consumer trust in the organisation is unthinkable without a personal relationship. The analysis of academic literature has shown that researchers often analyse the consumer confidence in the organisation itself, the impact of the organisation's reputation on consumer confidence (Keh \& Xie, 2009; Flavian et al., 2005), and less often discuss the impact of a CEO's or his image on consumer behaviour. The delivery of CEO's image to consumers and efforts to influence their trust in the organisation is not a very widely discussed issue. This situation demonstrates and shows the complexity of this topic and the clear need to explore this area much deeper and wider.

The continuous interest of scientists and practitioners is determined not only by the increasing importance of executive management for the success of the organisation, but also the complexity of the phenomenon itself and the abundance of its assessment prospects. However, regardless of the extent to which scientists attempt to cover their field of research, analysing the CEO image, its components, influential factors, there is hardly any research in academic literature that can answer the main scientific problem - how the image of CEO and its different elements affect consumer confidence in organisation itself? The first aim of our study it to analyse the influence of CEO image on the customer trust in the organisation. We consider the dimensions of integrity, competence, benevolence, and predictability that form consumer trust in the organisation (Gronroos, 2008; Lin \& Lu, 2010; Xie \& Peng, 2009). The second aim is to find out which elements of CEO image influence consumer trust in the organisation the most.

In order to meet these aims, the article deals with the structure of CEO image, analyses the dimensions determining consumer trust and develops a conceptual model that is verified by empirical research.

\section{Theoretical Background}

Elements of CEO image. The term of the CEO image has been studied in the intersection of various sciences, but psychologists, researchers of political sciences, management, sociology and human resource management, have dedicated special attention to this concept. The concept of CEO has been explored for decades, thus discovering new aspects of this concept every time, while the studies of the "leader's" concept, considered synonymous to it, were constantly changing and a dynamic process.

It should be noted that the major part of the research is dedicated to learning the characteristics of CEOs and their ability to influence. For example, the leadership researchers highlighted the leader's features and traits (Riggio, 2014), revealed management styles (Lee et al., 2011a; Mittal, 2015) and their diverse impact on performance, impact on the consumer decision making process and behaviour (de Leaniz, del Bosque Rodriguez, 2016). Antonakis and Day (2017) note that a number of scholars have attempted to identify and explain what the organisation's leader (CEO) should be, and what traits he needs to have. According to Mittal (2015), there are two charismatic and transformational theories of management that seek to explain how CEOs as leaders make followers to act in their favour and encourage working for the organisation's mission rather than material reward. According to Lee et al. (2011a), the transactional management and transformational management styles work most effectively and help to influence others to achieve positive organisational performance, such as customer orientation, job performance, trust, and role ambiguity. Criswell and Campbell (2011), examining the image aspect of the leader-manager, state that the image of the leader-manager is closely linked to the ability to perform well in the eyes of employees, consumers and other members of the public. It can be defined that CEO image is named as persons' feelings and attitudes in respect of the manager, determined by tangible and intangible elements, communication, personal and social values.

The leadership theory notes that there is a correlation between professional manager's characteristics and personal traits; therefore, the image is determined as an inseparable feature of the person. Contemporary market conditions require that $\mathrm{CEO}$ not only performs his professional and social function, but also builds the public opinion about the organisation or even the entire sector. Demonstration of power does not help to form the authoritative institution of the manager. It is precisely for this reason they state that CEO image must be a motivating force. First, CEO is a significant figure, which should be a model to follow for subordinates. Secondly, a positive CEO image leads to more cooperation that is moderate. This is justified with the consistent priority given to the positive CEO image, which becomes an example, motivating the team and each employee individually (Valieva et al, 2016). The concept of employer's image has become increasingly important not only in the human resource management but also in marketing management aspect (Lievens et al., 2007).

In order to demonstrate the peculiarities and structure of the development of CEO image, one can find different interpretations of what the CEO image covers. Valieva et al. (2016) state that the CEO image includes holistic and interrelated features and functions divided into internal and external:

- Features: (1) External - verbal, kinetic, linguistic; (2) Internal - temperament, character, motivation, orientation, interests, abilities.

- Functions: (1) External - representation function and communication function; (2) Internal - motivation function and regulatory function.

Zaccaro et al (2004), after conducting the meta-analysis of scientific and empirical research, distinguished 49 traits and characteristics of the manager grouped into groups: cognitive capacities and skills, personality, motives, social skills, task skills, self-beliefs, and knowledge.

According to the authors, the features and traits correlate with the achievements and performance of the leader, but multivariate and complex models are required to reveal the relationship between the traits and characteristics 
of the leader, and their impact on management processes, manager performance, manager role occupancy (Zaccaro et al., 2004). The highlighted features and characteristics of a leader-manager can be described by analysing whether CEOs conduct a financially successful business. They create added value to the society; attract investors; successfully compete in business; manage to achieve clearly formulated goals; form a professional team of employees; successfully defend the interests of the organisation; have achieved significant achievements in professional activities; is knowledgeable in the area for which they are responsible and constantly upgrades their skills.

Criswell, Campbell (2008) point out that, besides the characteristics and traits, the behaviour of CEOs with the groups of stakeholders is also of critical importance. CEOs as leaders, who are able to demonstrate the organisation's vision well, often have traits such as the ability to initiate and lead change, dynamism, far-sightedness/discernment, originality, and trust-building inspiration.

According to Clemmer (2003), executive management is linked to a differentiated psychological approach to different people; keeping a certain distance between your position and subordinates; discussions about problems among personnel and decision-making on the basis of the results of those discussions; allocation of responsibilities according to the position of employees and the determination of the coherent behaviour of the company. Park and Berger (2004) adapted Miller et al (1986) five dimensions referred to CEO character traits as competence, integrity, reliability, charisma, and personal. Authors analysed CEO's image dimensions in study media coverage of CEOs. Meanwhile, CEO who wants to reflect on a leader must seem independent; be able to inspire the surrounding people; to affect people; to be authoritative and influential in society; at the same time to be a public and well-known person; be innovative, agile and ambitious; promote organisational initiatives and build a vision and mission of the organisation (Zaccaro et al, 2004; Kalshoven, Hartog \& Hoogh, 2011).

After analysing the characteristics, traits and behaviour describing the CEO image, two main competencies forming the CEO image can be distinguished: managerial and sociopsychological (Table 1). The managerial competencies include professional and leader-manager qualities. The socio-psychological competence includes appearance, verbal/non-verbal behaviour, psychological characteristics, socio-demographic characteristics). These groups of factors reveal CEO's ability to represent and communicate to interested groups whose favours and confidence are sought.

Table 1

Elements of the CEO's Image

\begin{tabular}{|c|c|c|c|c|c|c|}
\hline \multirow{2}{*}{\multicolumn{3}{|c|}{ Managerial Competence }} & \multicolumn{4}{|c|}{ Socio-Psychological Competence } \\
\hline & & & \multirow{2}{*}{\multicolumn{2}{|c|}{$\begin{array}{c}\text { External traits (Park\&Berger, 2004; } \\
\text { Valieva et al, 2016) } \\
\text { Oral, kinetic, linguistic }\end{array}$}} & \multicolumn{2}{|c|}{$\begin{array}{c}\text { Internal traits (Park\&Berger, 2004; } \\
\text { Valieva et al, 2016) }\end{array}$} \\
\hline $\begin{array}{l}\text { Professional traits } \\
\text { (Park\&Berger, } \\
\text { 2004; Lee et al., } \\
\text { 2011a;) }\end{array}$ & $\begin{array}{r}\text { Leader's-manage } \\
\text { 2004; Park\&Be } \\
\text { Camp }\end{array}$ & $\begin{array}{l}\text { traits (Zaccaro et al, } \\
\text { er, 2004; Criswell, } \\
l 1,2008)\end{array}$ & & & Temperamen & character interests \\
\hline $\begin{array}{c}\text { Skills: } \\
\text { technical, human, } \\
\text { conceptual } \\
\end{array}$ & Management & Leadership & Appearance & $\begin{array}{l}\text { Verbal/nonverb } \\
\text { al behaviour }\end{array}$ & $\begin{array}{l}\text { Psychological } \\
\text { traits }\end{array}$ & $\begin{array}{c}\text { Socio- } \\
\text { demographic } \\
\text { characteristics }\end{array}$ \\
\hline $\begin{array}{l}\text { - Financially } \\
\text { successful activity } \\
\text { - Creating added } \\
\text { value; } \\
\text { - Attracting } \\
\text { investors; } \\
\text { - Successfully } \\
\text { competing } \\
\text { - Achieving } \\
\text { objectives } \\
\text { - Forming a } \\
\text { professional team } \\
\text { of employees } \\
\text { - Successfully } \\
\text { defending the } \\
\text { interests of the } \\
\text { organisation } \\
\text { - Presence of } \\
\text { significant } \\
\text { achievements in } \\
\text { professional } \\
\text { activities } \\
\text { - Responsibility for } \\
\text { the area } \\
\text { represented } \\
\text { - Skills are } \\
\text { constantly } \\
\text { updated }\end{array}$ & $\begin{array}{l}\text { - Differentiated } \\
\text { psychological } \\
\text { approach to } \\
\text { different people } \\
\text { - Maintaining the } \\
\text { distance } \\
\text { between your } \\
\text { position and } \\
\text { subordinates } \\
\text { - Team decision } \\
\text { making } \\
\text { - Delegates } \\
\text { responsibility } \\
\text { - Organize the } \\
\text { organisation's } \\
\text { activities in a } \\
\text { targeted manner. }\end{array}$ & $\begin{array}{l}\text { - Independent } \\
\text { - Inspiring others } \\
\text { - Authoritative } \\
\text { - Influential } \\
\text { - Publicity, } \\
\text { awareness } \\
\text { - Innovative } \\
\text { - Proactive } \\
\text { - Ambitious } \\
\text { - Innovative } \\
\text { - Clear vision }\end{array}$ & $\begin{array}{l}\text { - Stylish } \\
\text { appearance } \\
\text { - Consistency of } \\
\text { appearance } \\
\text { with the } \\
\text { occupied } \\
\text { position; } \\
\text { - Appropriate } \\
\text { accessories } \\
\text { - Neat hairstyle }\end{array}$ & $\begin{array}{l}\text { - Convincing } \\
\text { communication } \\
\text { in public } \\
\text { - Self-discipline } \\
\text { - Ability to } \\
\text { accept criticism } \\
\text { - High self- } \\
\text { control } \\
\text { - Confident in } \\
\text { appearance }\end{array}$ & $\begin{array}{l}\text { - Moral } \\
\text { - Ethical; } \\
\text { - Empathic } \\
\text { - Flexible } \\
\text { - Open } \\
\text { - Honest; } \\
\text { - Person } \\
\text { responsible } \\
\text { - Rational } \\
\text { - Principled } \\
\text { - Socially } \\
\text { responsible } \\
\text { - Has high } \\
\text { emotional } \\
\text { intelligence }\end{array}$ & 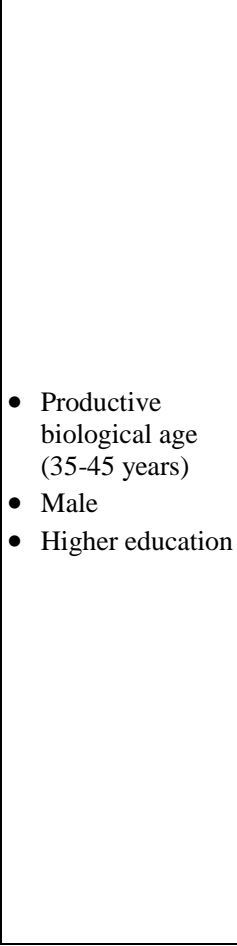 \\
\hline
\end{tabular}


Thus, CEO as a person becomes a much more significant object in the broad context of the corporate image. Which clearly shows that consumers, clients or even partners will always pay attention not only to the quality, price and delivery of goods or services, but also to the person who determines all these processes in their own organisation and how they will be able to engage in it and be attractive to interested groups of the organisations and gain their trust in the organisation (Park \& Berger, 2004). After examining the conceptual essence of CEO image, it can be argued that CEO image has a number of common links to the concept of consumer trust. CEO is always regarded as a person representing the organisation, which in turn means that consumers will be one of the main external stakeholders who will pay attention to the values that are being disseminated, the organisation's goals, the attitude of employees and society. This aspect is often very important for consumers when discussing whether a business is worth trusting.

Trust is a fundamental element of human relationships and one of the key elements for successful relationships. According to Dovaliene et al. (2007), for decades, overall customer satisfaction has been seen as one of the key factors determining the strength of relationships with consumers, their propensity and the ability to reduce consumer risks when purchasing goods or services. In scientific literature, trust is defined as the degree to which the consumer believes that the organisation is benevolent, integral and competent (Ryssel, Ritter \& Gemunden, 2004). Ulaga and Eggert (2004) argue that trust exists when there is a belief that the organisation will carry out activities that will benefit the consumer and unforeseen obstacles will be urgently removed in order to avoid harm. Fulmer, Gelfand (2012) defines interpersonal trust as "a psychological state comprising willingness to accept vulnerability based on positive expectations of a specific other or others ". Trust is described as a positive belief that another person will not be opportunistic - in words, actions or decisions - and that his intentions are motivated by principles of ethics and integrity (Tyler, 2003). Trust does not emerge immediately, but first by moving through certain stages of behaviour until a realistic trust in the specific individual is achieved. Scientists say that consumer trust in the organisation yields positive results (Verhoef et al., 2002). High consumer trust in the organisation determines consumers' reoccurring intention to buy (Lee et al., 2011b; Ponte et al., 2015), consumer satisfaction (Chinamona \& Dubihlela, 2014; Ponte et al., 2015), intention to cooperate with the organisation (e.g., sharing personal information, engaging in product development, Bowden, 2009).

Lin and $\mathrm{Lu}$ (2010) distinguish three dimensions of consumer trust in an organisation or a person, such as cognition, affection, and behaviour. Gronroos (2008), Lin, Lu (2010), Xie, Peng (2009) highlight the following dimensions of consumer trust:

- Ability/competence: the one being trusted has the influential knowledge, capability, and skills;

- Benevolence: the one being trusted is motivated to do something sincerely beneficial to others rather than to himself or herself;

- Integrity: means one another's openness and a guarantee that given promises are met;
- Predictability: a consumer can expect his needs to be satisfied first.

All these dimensions need to be managed in order to meet the needs of consumers and gain confidence. The consumer's desire to maintain trust-based relationships depends on the ability of the company to predict the needs of potential consumers and to satisfy them earlier than competitors. In this case, the corporate values, goals, mission and vision, which are implemented by CEO, are oriented towards the consumer and the satisfaction of his/her needs. Thus, the CEO's managerial competence and socio-psychological competence determine not overall CEO image, but customers' trust in the organisation, too.

\section{Conceptual Model and Research Hypothesis}

Considering that the CEO is a significant component of the company's image, it can be assumed that CEO's image, in general, and each of its elements is important and can influence consumer trust in the organization. The scientific research study limitation of CEO's image on consumer trust leads to certain assumptions:

- The image of a company that is shaped to gain consumer trust (Lin \& Lu, 2010). Jin \& Yeo (2011) states that the CEO's positive reputation play a significant role in building relationships with various publics and success of the company. Thus, CEO is an important part of the company image, and influences consumer trust in the organization.

- An effective image of CEO is a complex process of interaction between different personal and professional qualities and experiences, through which awareness and stimuli to act must be developed. The image of a CEO in literature includes elements such as professional skills; leadership; appearance; verbal/non-verbal behaviour; psychological and socio-demographic characteristics can influence consumer trust in an organization (Zaccaro et al., 2004; Criswell \& Cambell, 2008; Valieva et al., 2016).

Based on these assumptions, the research hypotheses are formulated. Figure 1 presents our conceptual model for the study, which comprises predicted theoretical links with research hypotheses to be tested in our empirical study.

Studies of the scientific literature highlighted that customers are interested in the behaviour of companies and CEO image and reputation has an influence to overall company reputation (Park \& Berger, 2004; Zameer et al., 2015). However, the theoretical overview of the concept of a trust has allowed it to be substantiated that in order to achieve a high level of consumer trust in the organisation, everyone involved with the organisation must feel responsible and work ethically, professionally and with integrity. In addition, in order to create a high level of consumer trust, it is worth noting that the CEO's image becomes a sufficiently important aspect that can have both positive and negative influence. Ingenhoff, Sommer (2010) note that CEO is always considered as a person representing the organisation, which in turn means that consumers, as one of the main external stakeholders will evaluate the personality of CEO and its influence on the organisation's activities. 


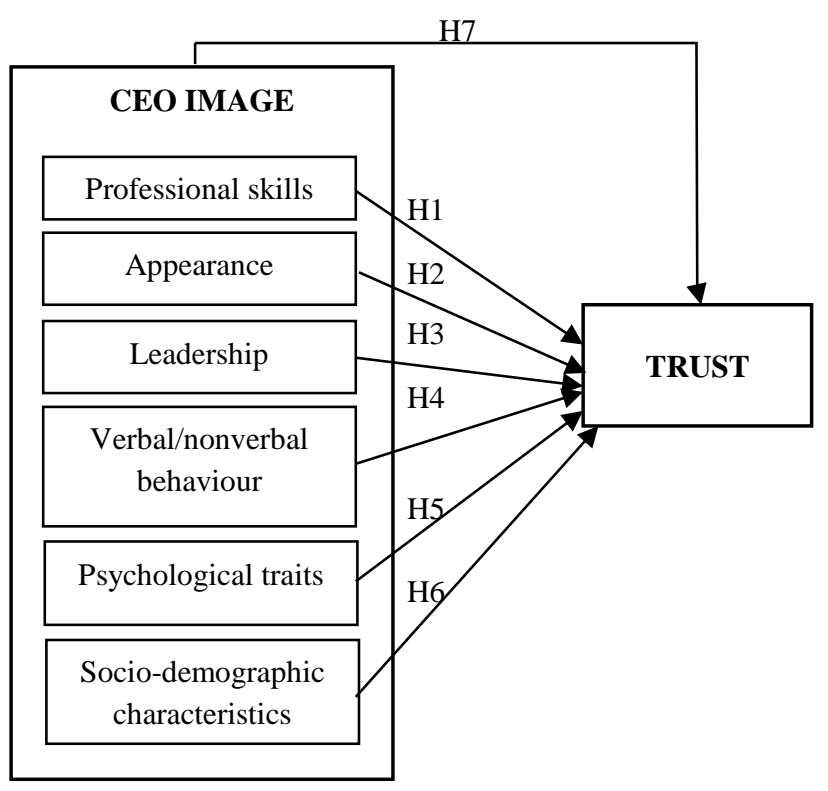

Figure 1. Influence of CEO Image on the Customer Trust in the Organisation: Research Framework

Scientific literature study shows that the managerial and social-psychological competencies of CEOs can affect the consumer trust in the organisation. The managerial and socio-psychological competencies of CEO image highlighted in Table 1 are revealed through the appropriate qualities and traits that were analysed by Clemmer (2003), Zaccaro et al. (2004), Riggio (2014), Valieva et al. (2016). Leadership science researchers such as Criswell and Cambell (2011), Lee et al. (2011a), by analysing the expression of leadership and leadership styles, have revealed the corresponding behaviour of the leader-manager and its effects on stakeholders. For example, the leadership researchers described the leader's features and traits (Riggio, 2014), revealed management styles (Lee et al., 2011a; Mittal, 2015) and their diverse impact on performance, impact on the consumer decision making process and behaviour (de Leaniz, del Bosque Rodriguez, 2016). Antonakis and Day (2017) noted that a number of scholars have attempted to identify and explain what the organisation's leader (CEO) should be, and what traits he needs to have.

Therefore, the following research question and hypotheses are posited:

RQ1: Which elements of a CEO image have significant influence on customers' trust in the organisation?

H1 CEO's professional skills affect the consumer trust in the organisation.

H2 CEO's leadership affects the consumer trust in the organisation.

H3 CEO's appearance affects the consumer trust in the organisation.

H4 CEO's verbal/non-verbal behaviour affects the consumer trust in the organisation.

H5 CEO's psychological characteristics affect the consumer trust in the organisation.

H6 CEO's socio-demographic characteristics affect the consumer trust in the organisation.
It is also important to keep in mind that CEO, based on theirs perceived values (which is part of the CEO image), determines the company's future vision and mission, thus influencing how the organisation will act in long perspective. This aspect is often very important for consumers when discussing whether a business is worth trusting. On the other hand, CEO is a person closest to the employees, therefore, if the latter is not satisfied with the image created by CEO's, it will certainly be felt by the consumers of the organisation, who, seeing the negative feedback from the employees, may change their degree of trust towards the whole organisation. Studies of the scientific literature highlighted the four main dimensions of consumer trust in the organisation: integrity, benevolence, competence, predictability.

RQ2: What is the influence of the overall CEO image on the consumer trust in the organisation?

H7 hypothesis, which states that the impact of CEO image and its elements on the consumer trust in the organisation, varies depending on the assessment of CEOs (positive/negative).

\section{Research Design and Methods}

The aim of the research was to explore the influence of identified elements of CEO image on the consumer trust in the organisation (see Fig. 1).

In order to verify the impact of CEO image on consumer trust in organisation, an empirical study was conducted to answer the research questions:

RQ1: Which elements of CEO image have significant influence on consumer trust in the organisation?

RQ2: What is the influence of the overall CEO image on the consumer trust in the organisation?

Survey includes questions on five dimensions of CEO image that impact consumers' trust in organization, respondents' demographic characteristics. In the beginning, respondents had to identify CEOs names which/whom they knew, that we made sure about which CEO they had to answer the questionnaire.

Dimensions demonstrating CEO image such as professional skills (created added value, attracted investors, successfully competing), leadership (as inspiring others, authoritative influential and publicity, awareness), appearance (stylish appearance, style matching with position et.), verbal/nonverbal; behaviour (self-discipline, ability to accept criticism; high self-control) and psychological traits were used in order to determine CEO image influence on the consumer trust. To analyse these five CEO image elements, the items were adapted from works Park\&Berger (2004); Valieva et al, 2016); Kalshoven, Hartog, Hoogh (2011), Zaccaro et al. (2004); Criswell \& Campbell, 2008). Participants were asked to evaluate the given statements on a 5 - point Likert scale ( $1=$ strongly disagree to $5=$ strongly agree). Based on the research of these authors, statements that reveal the concept of CEO image were prepared.

The CEOs chosen for the empirical research represent different business sectors, and have the average age of 53 years. Based on this fact, it can be argued that these CEOs and their managed companies are well known to many residents of Lithuania from the age of 18. In order to assess 
the impact of a CEO image to the consumer trust in the organisation, CEOs of Lithuanian companies included in the list of the 20 richest people in Lithuania in 2018 were selected. The list included CEOs with many years of professional and personal experience, managing companies successful and profitably and having the outstanding image of the organisation and of their own, as personalities and executives. All CEOs are often seen in public, cited and interviewed by media representatives who express a solid view on the matters of business and economics. For example, in 2013-2018, the company Hanner (real estate development leader in Lithuania and foreign countries) CEO Arvydas Avulis was mentioned, cited and interviewed for a total of 4,260 times in the three largest and most popular news portals in Lithuania (www.delfi.lt, www.15min.lt and www.lrytas.lt). Benas Gudelis (CEO of Fragrances International. Company is a leader in the wholesale of selective cosmetics and perfumery in the Baltic States) - 3,147 times, and Nerijus Numavicius (shareholder and CEO of Vilniaus Prekyba) - 2,343 times.

A quantitative research approach has been used to achieve the purpose of research by applying the online survey method. Questionnaires providing only closed-type questions have been sent by e-mail for respondents selected using the convenience sampling method. The research was conducted in 2018. 235 answers were received, but only 186 questionnaires were recognized as usable for further analysis. 186 respondent answers that know very well a chosen CEO.

In total, 186 questionnaires completed by respondents were used for the data processing; whereas women accounted for a bigger share of respondents, i.e. $76.9 \%(n=143)$, and men $-23.1 \%(n=43)$. The results of the research showed that the distribution of respondents in the age groups is quite similar: most of the participants were in the age groups of 26-35 years (27.4\%) and 36-45 years (29\%). Respondents answering the least questions of the questionnaire were in the age groups of $46-55$ years $(15.1 \%)$ and 56 years and more $(12.4 \%)$.

The reliability of the questionnaire indicates the ability of the measuring instrument to produce similar results each time the instrument is used for a similar study. Thus, the Cronbach's alpha coefficient method was used to verify the validity of the questionnaire. This coefficient helps to assess the structural elements of the questionnaire, in this case, the statements about CEO image and the consumer trust in the organisation (Table 2).

Reliability of the Research Questionnaire Scales

Table 2

\begin{tabular}{|c|c|c|}
\hline Element scales & $\begin{array}{c}\text { Cronbach's } \\
\text { alpha }\end{array}$ & $\begin{array}{c}\text { Number of } \\
\text { claims }\end{array}$ \\
\hline CEO image: & $\mathbf{0 . 9 5 1}$ & $\mathbf{4 9}$ \\
\hline Professional skills & 0.839 & 10 \\
\hline Leadership & 0.851 & 11 \\
\hline Appearance & 0.835 & 8 \\
\hline $\begin{array}{c}\text { Verbal/nonverbal } \\
\text { behaviour }\end{array}$ & 0.765 & 6 \\
\hline Psychological traits & 0.893 & 11 \\
\hline $\begin{array}{c}\text { Socio-demographic } \\
\text { characteristics }\end{array}$ & 0.386 & 3 \\
\hline $\begin{array}{c}\text { Consumer trust in the } \\
\text { organisation }\end{array}$ & $\mathbf{0 . 7 7 4}$ & $\mathbf{4}$ \\
\hline Total & 0.953 & 53 \\
\hline
\end{tabular}

The total reliability of the scales is estimated at 0.953 . The Cronbach's alpha coefficient for this study questionnaire is significantly higher than the minimum coefficient indicated in the methodological guidelines. It can be assumed that there is a relatively high consistency among all the elements of the questionnaire and all components of the questionnaire are very reliable. However, it was decided to exclude the socio-demographic characteristics sub-scale from the study due to the latter's low Cronbach's alpha coefficient and very insignificant (0.072 and 0.135$)$ or only average (0.469) correlation between the elements. After checking the reliability of the scales, the factor analysis method was used to further analyse the results of the research, which makes it possible to verify the reliability of selection of elements of each component of CEO image and whether the factor analysis is effective. The purpose is also to identify whether the scales measure the aspects necessary for the research and whether there is a need to reject or redistribute certain elements. The factorial analysis showed that, despite the fact that the reliability of the newly created scales in the research being rather high, it is necessary to abandon certain elements of the scales in order to carry out further analysis.

Table 3 contains the statements used for further analysis of the CEO image.

Analysed Statements after Factor Analysis

Table 3

\begin{tabular}{|c|c|}
\hline Elements & $\begin{array}{r}\text { Sub-dimensions } \\
\end{array}$ \\
\hline $\begin{array}{l}\text { Professional } \\
\quad \text { skills }\end{array}$ & $\begin{array}{l}\text { - } \quad \text { Created added value } \\
\text { - } \quad \text { Attracted investors } \\
\text { - Successfully competing } \\
\end{array}$ \\
\hline Leadership & $\begin{array}{ll}\text { - } & \text { Inspiring others } \\
\text { - } & \text { Authoritative Influential } \\
\end{array}$ \\
\hline Appearance & $\begin{array}{l}\text { - Stylish appearance; } \\
\text { - Matching appearance with the occupied } \\
\text { position } \\
\text { - Correct matching of accessories }\end{array}$ \\
\hline $\begin{array}{c}\text { Verbal/nonverbal } \\
\text { behaviour }\end{array}$ & $\begin{array}{l}\text { - Self-discipline } \\
\text { - } \quad \text { Ability to accept criticism } \\
\text { - High self-control }\end{array}$ \\
\hline $\begin{array}{c}\text { Psychological } \\
\text { traits }\end{array}$ & $\begin{array}{l}\text { - } \text { Moral } \\
\text { - } \\
\text { Ethical } \\
\text { - } \text { Empathic } \\
\text { - } \text { Openible } \\
\text { - Honest } \\
\text { - } \text { Socially responsible } \\
\end{array}$ \\
\hline
\end{tabular}

The data of the empirical study was encoded and analysed using the IBM SPSS Statistics 20.0 version of the research data analysis software. A linear regression analysis method was used to test the hypothesis of the research. It allowed to simulate the value of the scale variable by justifying its linear relations with other variables.

\section{Empirical results}

Summing up the distribution of the respondents responses, frequencies and deviations, it was observed that the majority of respondents (consumers) ground their opinion on the CEO image on their knowledge from media $(60.9 \%)$. This potentially explains why respondents were not able to specify whether CEO is constantly updating his skills $(29 \%)$, encouraging initiatives in the organisation 
$(25.8 \%)$, being able to accept criticism $(30.6 \%)$, or whether CEO is honest (36\%) and whether their chosen CEO has higher education $(31.2 \%)$.

Most respondents supported the statements that presented CEOs are self-confident $(80.6 \%)$, are a public and well-known figure $(88.2 \%)$, have significant professional achievements $(77.4 \%)$, is influential in society (79\%) and his appearance is in line with the position occupied (77.4\%) and seems independent $(74.7 \%)$. According to the respondents, the chosen manager is the authority (74.8\%), is knowledgeable in the area he is responsible for $(74.2 \%)$ and maintains extensive business relations (62.3\%), successfully communicates in public $(55.3 \%)$ and is responsible $(53.3 \%)$. Analysing the most disapproved statements, no more significant tendencies were found, except for the attribution of CEO's age to the most productive age $(53.8 \%)$ and high self-control $(37.1 \%)$. Such results can be explained by the fact that the majority of respondents chose a much older manager with a rather "sharp" character.

From the aspect of the consumer trust in the organisation, it has been observed that $50 \%$ of respondents believe that an organisation headed by the selected CEO will provide and sell them good service or product. One fifth of respondents do not believe that the organisation led by the chosen CEO will keep its promises, important for consumers $(21.5 \%)$.

Scale dependence and distribution of the questionnaire variables were determined using the Kolmogorov-Smirnov test. The Kolmogorov-Smirnov test showed that the value of the variables $p$ is less than 0.05 , and one of the elements - Psychological traits - is higher (0.200). Others variables are not normally distributed, in the subsequent correlation analysis, it was decided to use the Spearman's coefficient, which is less sensitive and can be used in various cases.

In order to verify whether the consumer trust in the organisation is related to the corporate manager's image, a correlation analysis (Table 4) was carried out to determine the relationship between consumer trust in the organisation and CEO image elements as skills, leadership, appearance, verbal/non-verbal behaviour, and CEO's psychological traits.

It can be argued that the relationship between the consumer trust in the organisation and the CEO image and its elements are in fact statistically significant, the relationship is positive rather than opposite. The relationship between consumer trust and CEO's leadership, appearance guide and professional skills is low. Meanwhile, the relationships between other variables already reach the average correlation coefficient. The strongest relation is seen among the consumer trust in the organisation and CEO's psychological traits (0.502).

After analysing the statistical relationship between the analysed variables, a regression analysis was performed. It allowed checking whether CEO image and its elements influence the consumer trust in the organisation.
Table 4

Results of Correlation Analysis

\begin{tabular}{|c|c|c|}
\hline $\begin{array}{c}\text { Elements of CEO } \\
\text { image }\end{array}$ & Correlation results & Consumer trust \\
\hline \multirow{2}{*}{ Professional skills } & $\begin{array}{l}\text { Coefficient of } \\
\text { correlation }\end{array}$ & $0.332 * *$ \\
\hline & $\mathrm{P}$ - value & 0.000 \\
\hline \multirow[t]{2}{*}{ Leadership } & $\begin{array}{l}\text { Coefficient of } \\
\text { correlation }\end{array}$ & $0.250 * *$ \\
\hline & $\mathrm{P}$ - value & 0.001 \\
\hline \multirow[t]{2}{*}{ Appearance } & $\begin{array}{l}\text { Coefficient of } \\
\text { correlation }\end{array}$ & $0.331 * *$ \\
\hline & $\mathrm{P}-$ value & 0.000 \\
\hline \multirow{2}{*}{$\begin{array}{l}\text { Verbal/nonverbal } \\
\text { behaviour }\end{array}$} & $\begin{array}{l}\text { Coefficient of } \\
\text { correlation }\end{array}$ & $0.466^{* *}$ \\
\hline & $\mathrm{P}-$ value & 0.000 \\
\hline \multirow[t]{2}{*}{ Psychological traits } & $\begin{array}{l}\text { Coefficient of } \\
\text { correlation }\end{array}$ & $0.502 * *$ \\
\hline & $\mathrm{P}-$ value & 0.000 \\
\hline
\end{tabular}

The multiplying linear regression (Table 5) shows that the Pearson's correlation coefficient is moderately strong ( $\mathrm{r}$ $=0.600)$, which, in turn, means that the relationship between consumer trust in the organisation and CEO image is moderately strong. Determination coefficient (R Square) R2 $=0.360$ and Adjusted R Square do not differ distinctly ( $2 \mathrm{adj}=0.342)$, thus it can be stated that the five elements of CEO image explain almost $35 \%$ of the data distribution for the variable of consumer trust in the organisation. The determination coefficient is greater than 0.2 and indicates that the regression model is suitable for this research and can be applied.

Table 5

Summary of the Regression Model

\begin{tabular}{|c|c|c|c|}
\hline $\mathbf{R}$ & $\begin{array}{c}\mathbf{R} \\
\text { Square }\end{array}$ & Adjusted R Square & $\begin{array}{c}\text { Standard error } \\
\text { estimation }\end{array}$ \\
\hline $0.600 \mathrm{a}$ & $\mathbf{0 , 3 6 0}$ & 0.342 & 3.96364 \\
\hline
\end{tabular}

The ANOVA table shows that the coefficient of at least one of the variables is not zero, which also confirms that the model is suitable for regression analysis (Mertler, Reinhart, (2016). It should be noted that the $p$-value coefficient is less than 0.05 , therefore it can be stated that the regression model can be used (Table 6).

Table 6

Results of ANOVA Analysis

\begin{tabular}{|l|c|c|c|c|c|}
\hline \multicolumn{1}{|c|}{ Model } & $\begin{array}{c}\text { Sums of } \\
\text { squares }\end{array}$ & df & $\begin{array}{c}\text { Average of } \\
\text { squares }\end{array}$ & F & $\begin{array}{c}\boldsymbol{p}- \\
\text { value }\end{array}$ \\
\hline Regression & 1580.831 & 5 & 316.166 & 20.125 & $0.000 \mathrm{~b}$ \\
\hline Residual & 2812.175 & 180 & 15.710 & & \\
\hline Total & 4393.005 & 185 & & & \\
\hline
\end{tabular}

Regression coefficient table (see Table 7) shows that the four of the five variable coefficients are statistically significant, i.e. the $p$-value of the variable is less than 0.05 (Professional abilities $p$-value $=0.000$; Appearance $p$-value $=0.006 ;$ Verbal $/$ non-verbal behaviour $p$-value $=0.000$; Psychological traits $p$-value $=0.000)$. One remaining variable (Leadership $p$-value $=0.084$ and) is not so important in explaining the consumer trust in the organisation, because its $p$-value exceeds the coefficient 0.05 .

The Beta column shows the strengths of the relations obtained by the regression analysis, which indicate that the 
higher the value of the coefficient, the stronger the independent variable influences the dependent (in this case, the consumer trust in the organisation). The consumer trust in the organisation is most affected by Psychological traits $(\beta=0.368)$ and Verbal/non-verbal behaviour $(\beta=0.353)$; the lowest - by Leadership $(\beta=0.104)$.

Thus, following a multiple linear regression analysis, it has been found that:

- H1 hypothesis, which states that CEO's professional skills affect the consumer trust in the organisation, was confirmed because the $p$-value of this variable was 0.000 , which means that $\mathrm{p}<0.05$, therefore, it is a statistically significant relationship that influences the consumer trust in the organisation. The influence of this variable is moderately strong $(\beta=0.249)$.

- H2 hypothesis is picking that CEO's leadership affects the consumer trust in the organisation was not verified because the $p$-value of this variable was 0.084 , which means that $p$ > 0.05 , thus, it is a statistically insignificant relation that has the lowest influence $(\beta=0.104)$ consumer trust in the organisation.

- H3 hypothesis, which states that the appearance of CEO's affects the consumer trust in the organisation, was confirmed as the $p$-value of this variable was 0.006 , which means that $\mathrm{p}<0.05$, thus it is a statistically significant relationship that affects the consumer trust in the organisation. The influence of this variable is of moderate strength $(\beta=$ 0.165 ) in comparison with all objects in the list of variables.

- The H4 hypothesis that the verbal/non-verbal behaviour of CEO's affects the consumer trust in the organisation was confirmed as the $p$-value of this variable was 0.000 , which means that $\mathrm{p}<0.05$, therefore, it is considered to be a statistically significant relation having some of the strongest influences $(\beta=0.353)$ on consumer trust in the organisation.

- The H5 hypothesis, which states that the psychological traits of CEO's influence the consumer trust in the organisation, was confirmed because the $p$-value of this variable was 0.000 , which means that $\mathrm{p}<0.05$, therefore it is a statistically significant relation that influences the consumer trust in the organisation. The influence of this variable is the largest $(\beta=$ 0.368 ) from the total list of variables.

- H6 hypothesis, which states that the socio-demographic characteristics of CEO's influence consumer trust in the organisation was not verified because during the scrutiny of the credibility of the subscale it appeared that this subscale has been drafted by incorrectly formulating the statements, therefore, this hypothesis was no longer considered in further analysis of the research data.

Verifying the hypotheses H1-H6 was found that the greatest influence on consumer trust is made by Professional Skills, Verbal/non-verbal and Psychological traits.

$\mathrm{H} 7$ hypothesis, which states that the impact of the CEO image and its elements on the consumer trust in the organisation varies depending on CEO image assessment (positive/negative), requires additional actions of the linear regression analysis. Therefore, in order to confirm this hypothesis, the changes on the influence made by the variables when CEO is assessed positively or negatively, were distinguished.

Table 7

Results of the Regression Analysis

\begin{tabular}{|c|c|c|c|c|c|}
\hline \multirow[t]{2}{*}{ Independent variables* } & \multicolumn{2}{|c|}{ Non-standardized coefficients } & \multirow{2}{*}{$\begin{array}{c}\text { Standardized coefficients } \\
\beta\end{array}$} & \multirow[t]{2}{*}{$\mathbf{T}$} & \multirow[t]{2}{*}{ P-value } \\
\hline & B & Standard error & & & \\
\hline Professional skills & 1.218 & 0.292 & 0.249 & 4.1700 & 0.000 \\
\hline Leadership & 0.508 & 0.292 & 0.104 & 1.738 & 0.084 \\
\hline Appearance & 0.806 & 0.292 & 0.165 & 2.758 & 0.006 \\
\hline Verbal/nonverbal behaviour & 1.725 & 0.292 & 0.353 & 5.903 & 0.000 \\
\hline Psychological traits & 1.796 & 0.292 & 0.368 & 6.146 & 0.000 \\
\hline
\end{tabular}

*Independent variables are professional skills, leadership, appearance, verbal/non-verbal behaviour, psychological traits.

**The dependent variable is the consumer trust in the organisation

Meanwhile, after selecting the answers of respondents who assessed CEOs positively, it was found that Verbal/Non-verbal behaviour and Psychological traits have the biggest effect (Table 8). After selecting the answers of the respondents who assessed CEOs negatively, it turned out that the consumer trust in the organisation is already affected not only by Verbal/non-verbal behaviour and Psychological traits, but also by one more variable Professional skills.
The results of the regression analysis in the evaluation of the overall influence of the CEOs image on the consumer trust in the organisation, when the manager was assessed positively, negatively and neutrally, are presented in Table 9. It can be stated that the influence of CEO image on the consumer trust in the organisation is undoubted, but in assessing the strength of this influence, it is always necessary take into account the context and see the circumstances that may be the causes of certain outcomes, as was the case with the assessment of CEO image.

Table 8

Comparative Results of Regression Analysis

\begin{tabular}{|c|c|c|c|c|c|c|}
\hline \multirow{2}{*}{ Independent variables } & \multicolumn{2}{|c|}{ Total } & \multicolumn{2}{|c|}{ Positive } & \multicolumn{2}{|c|}{ Neutral } \\
\hline & $\beta$ & $p$ & $\beta$ & $p$ & $\beta$ & $p$ \\
\hline Professional skills & 0.249 & 0.000 & 0.084 & 0.396 & 0.285 & 0.006 \\
\hline Leadership & 0.104 & 0.084 & -0.018 & 0.852 & 0.162 & 0.127 \\
\hline Appearance & 0.165 & 0.006 & 0.159 & 0.097 & 0.139 & 0.150 \\
\hline Verbal/nonverbal behaviour & 0.353 & 0.000 & 0.329 & 0.001 & 0.460 & 0.000 \\
\hline Psychological traits & 0.368 & 0.000 & 0.434 & 0.000 & 0.238 & 0.023 \\
\hline
\end{tabular}


Comparative Results of Regression Analysis

\begin{tabular}{|l|c|c|c|c|c|c|c|}
\hline \multirow{2}{*}{ Independent variables } & \multicolumn{2}{|c|}{ Total } & \multicolumn{2}{|c|}{ Positive } & \multicolumn{2}{c|}{ Negative } \\
\cline { 2 - 8 } & $\beta$ & $p$ & $\beta$ & $p$ & $\beta$ & $p$ & $\beta$ \\
\hline CEO image & 0.554 & $\mathbf{0 . 0 0 0}$ & 0.429 & $\mathbf{0 . 0 0 0}$ & 0.073 & 0.705 & 0.600 \\
\hline
\end{tabular}

Thus, it can be concluded that the $\mathrm{H} 7$ hypothesis, which states that the influence of CEO image and its elements on the consumer trust in the organisation varies depending on the assessment of CEOs (positive/negative), was confirmed.

In order to implement the purpose of this research, i.e. empirically substantiate the theoretical model of the influence of CEO image elements on the consumer trust in the organisation; correlation and regression analyses were carried out with the results allowing to verify the hypotheses raised at the beginning of the research (Table 10).

The results of verification of the research hypotheses presented in Table 10 allowed to justify the theoretical model of the conceptual influence of CEO image on the consumer trust in the organisation, used as a basis of performing the empirical research.

The Rèsult of Verification of Empirical Research Hypotheses

\begin{tabular}{|c|c|c|}
\hline \multicolumn{2}{|r|}{ Hypothesis } & Result \\
\hline $\mathrm{H} 1$ & CEO's professional skills affect the consumer trust in the organisation. & Accepted \\
\hline $\mathrm{H} 2$ & CEO's leadership affects the consumer trust in the organisation. & Not accepted \\
\hline $\mathrm{H} 3$ & CEO's appearance affects the consumer trust in the organisation. & Accepted \\
\hline $\mathrm{H} 4$ & CEO's verbal/non-verbal behaviour affects the consumer trust in the organisation. & Accepted \\
\hline H5 & CEO's psychological characteristics affect the consumer trust in the organisation. & Accepted \\
\hline H6 & CEO's socio-demographic characteristics affect the consumer trust in the organisation. & Not accepted \\
\hline H7 & $\begin{array}{l}\text { The influence of the elements of CEO image to the consumer trust in the organisation differs } \\
\text { depending on the assessment of CEO image (positive/negative/neutral). }\end{array}$ & Accepted \\
\hline
\end{tabular}

Based on the research data it was found that the greatest influence on the consumer trust in the organisation is made by Psychological traits $(\beta=0.368)$ and Verbal/non-verbal behaviour $(\beta=0.353)$; the lowest - by Leadership $(\beta=$ $0.104)$. It was also confirmed that the strength of the influence of the consumer trust in the organisation varies depending on how the overall CEO image is evaluated. The results of the research revealed the fact that the biggest influence of CEO image is when the overall CEO image is assessed by consumers neutrally, and the least influence is made when CEO is assessed negatively. Consequently, the results of the conceptual model's statistical justification make it possible to determine the possibilities of practical application of the obtained results and the suitability of the prepared model for further research.

Summarizing the results of the research it can be stated that this study data analysis is the initial iteration for further research of such an objective and encourage a deeper insight into the topic of CEO image influencing the consumer trust in the organisation and in conducting similar scientific research in order to substantiate the research model and its reliability.

\section{Discussion and Conclusions}

The marketing, public relations and leadership literature acknowledges the importance of CEO image to overall organization image and influence customer's behavior (Flavian et al., 2005; de Leaniz \& del Bosque Rodriguez, 2016). Despite that the majority of the studies have been approached from a fundamentally theoretical perspective, examines corporate image and reputation influence to customer behaviour, and just few studies examine how CEOs image impact customers' trust in the organisations (Park \& Berger, 2004; Ingenhoff \& Sommer, 2010; Jin \& Yeo, 2011). Ingerhoff and Sommer (2010) noted that it is very important to analyse not only organization image and reputation influence to consumer trust, but also CEO as a trustee. Authors investigated that CEO and organisation when combined with customer satisfaction may be closely related to organisation credibility.

Our research results disclosed CEO image structure and elements and confirm that professional skills, verbal/nonverbal behaviour, psychological traits of CEO have significant influence to consumer trust in the organisation. As noticed Jin and Yeo (2011) evaluation of CEO image depends on information in media and does it positively or negatively slanted about the company and its CEO. Most of our respondents formed image of CEO from media.

Our research confirmed Ingenhoff and Sommer (2011) research results that it is important for the customers do the CEOs keep their promises, are they socially responsible. The psychological traits have a positive impact to consumer trust in CEO, they believe that organisation provide and sell them good quality products and services. Our study contributes to the literature on the value of CEOs image and reputation, because empirical findings provide merit insights for public relation practitioners. Managers from public relations departments have to make a clear strategy of CEO image and organisational image creation in the publicity. Customers trust more in organisations when CEO image is more positive in the publicity and vice versus.

Based on the analysis of scientific literature it can be assumed that the number of elements of CEO image professional skills, leadership, appearance, verbal/nonverbal behaviour, psychological traits, which influence the consumer trust in the organisation, can be either higher or the distribution could be entirely different according to the different research goals. This means that the search and analysis of additional new elements could be one of the directions for developing the model. 
Since we did not succeed to analyse and evaluate the influence of the socio-demographic characteristics of the $\mathrm{CEO}$ in this research, subsequent research on this topic, primarily, could be focused in particular on the inclusion of the socio-demographic characteristics of CEO in the research instrument. Our research did not focus on a specific business sector or company CEO whereof could have become the subject of the whole research work, but this allows using this research instrument much wider in further research, exploiting its versatility and independently adapting certain aspects of the questionnaire, to investigate how the influence of a CEO image on the consumer trust in the organisation varies depending on the analysed context, selected company or the specifically indicated CEOs.
By verifying the conceptual model of the influence of a CEO image on the consumer trust in the organisation, no interrelations of the respondent demographic/behaviour characteristics with the analysed model constructs were investigated. Therefore, in the future research, we suggest that linking the results of research of the influence of CEO image on the consumer trust in the organisation with the characteristics of respondents such as age, sex, monthly income, etc. The results of this kind of research could help to clarify how the assessment of CEO image may depend on the socio-demographic characteristics of different respondents and enhance the possibilities for practical application, for example, in order to segment consumers or to position offers prepared for them.

\section{References}

Antonakis, J., \& Day, D. V. (Eds.). (2017). The nature of leadership. Sage publications.

Bonett, D. G., \& Wright, T. A. (2015). Cronbach's alpha reliability: Interval estimation, hypothesis testing, and sample size planning. Journal of Organizational Behavior, 36(1), 3-15. https://doi.org/10.1002/job.1960

Bowden, J. L. H. (2009). The process of customer engagement: A conceptual framework. Journal of Marketing Theory and Practice, 17(1), 63-74. https://doi.org/10.2753/MTP1069-6679170105

Boyd, B. K., \& Solarino, A. M. (2016). Ownership of corporations: A review, synthesis, and research agenda. Journal of Management, 42(5), 1282-1314. https://doi.org/10.1177/0149206316633746

Clemmer, J. (2003). The leader's digest: Timeless principles for team and organization success. Canada: TCG Press.

Criswell, C., \& Campbell, D. P. (2011). Building an authentic leadership image (Vol. 121). John Wiley \& Sons.

de Leaniz, P. M. G., \& del Bosque Rodriguez, I. R. (2016). Corporate image and reputation as drivers of customer loyalty. Corporate Reputation Review, 19(2), 166-178. https://doi.org/10.1057/crr.2016.2

Flavian, C., Guinaliu, M., \& Torres, E. (2005). The influence of corporate image on consumer trust: A comparative analysis in traditional versus internet banking. Internet Research, 15(4), 447-470. https://doi.org/10.1108/106622 40510615191

Fulmer, C. A., \& Gelfand, M. J. (2012). At what level (and in whom) we trust: Trust across multiple organizational levels. Journal of Management, 38(4), 1167-1230. https://doi.org/10.1177/0149206312439327

Gozukara, I., \& Yildirim, O. (2015). Affective commitment and corporate reputation. The effects of attitude toward advertising and trust. Academic Journal of Economic Studies, 1(3), 126-147.

Gronroos, C. (2008). Service logic revisited: who creates value? And who co-creates? European Business Review, 20(4). https://doi.org/10.1108/09555340810886585

Helm, S., Eggert, A., \& Garnefeld, I. (2010). Modeling the impact of corporate reputation on customer satisfaction and loyalty using partial least squares. In Handbook of partial least squares (pp. 515-534). Springer, Berlin, Heidelberg. https://doi.org/10.1007/978-3-540-32827-8_23

Jin, C. H., \& Yeo, H. C. (2011). Satisfaction, corporate credibility, CEO reputation and leadership effects on public relationships. Journal of Targeting, Measurement and Analysis for Marketing, 19(2), 127-140. https://doi.org/10.1057/jt.2011.10

Kalshoven, K., Den Hartog, D. N., \& De Hoogh, A. H. (2011). Ethical leadership at work questionnaire (ELW): Development and validation of a multidimensional measure. The Leadership Quarterly, 22(1), 51-69. https://doi.org/10.1016/j.leaqua.2010.12.007

Keh, H. T., \& Xie, Y. (2009). Corporate reputation and customer behavioral intentions: The roles of trust, identification and commitment. Industrial Marketing Management, 38(7), 732-742. https://doi.org/10.1016/j.indmarman. 2008.02.005

Lee, J., Park, D. H., \& Han, I. (2011b). The different effects of online consumer reviews on consumers' purchase intentions depending on trust in online shopping malls: An advertising perspective. Internet Research, 21(2), 187-206. https://doi.org/10.1108/10662241111123766

Lee, Y. K., Son, M. H., \& Lee, D. J. (2011a). Do emotions play a mediating role in the relationship between owner leadership styles and manager customer orientation, and performance in service environment? International Journal of Hospitality Management, 30(4), 942-952. https://doi.org/10.1016/j.ijhm.2011.02.002

Lievens, F., \& Slaughter, J. E. (2016). Employer image and employer branding: What we know and what we need to know. Annual Review of Organizational Psychology and Organizational Behavior, 3, 407-440. https://doi.org/10.1146/ annurev-orgpsych-041015-062501 
Lievens, F., Van Hoye, G., \& Anseel, F. (2007). Organizational identity and employer image: Towards a unifying framework. British Journal of Management, 18, S45-S59. https://doi.org/10.1111/j.1467-8551.2007.00525.x

Lin, L. Y., \& Lu, C. Y. (2010). The influence of corporate image, relationship marketing, and trust on purchase intention: the moderating effects of word-of-mouth. Tourism Review, 65(3), 16-34. https://doi.org/10.1108/1660 5371011083503

Mertler, C. A., \& Reinhart, R. V. (2016). Advanced and multivariate statistical methods: Practical application and interpretation. Routledge.

Minchington, B. (2017). Global view of Employer Brand excellence-part 2. HR Future, 2017 (Sep 2017), 14-15.

Mittal, R. (2015). Charismatic and transformational leadership styles: A cross-cultural perspective. International Journal of Business and Management, 10(3), 26. https://doi.org/10.5539/ijbm.v10n3p26

Nguyen, N., \& Leblanc, G. (2001). Corporate image and corporate reputation in customers' retention decisions in services. Journal of Retailing and Consumer Services, 8(4), 227-236. https://doi.org/10.1016/S0969-6989(00)00029-1

Park, D. J., \& Berger, B. K. (2004). The presentation of CEOs in the press, 1990-2000: Increasing salience, positive valence, and a focus on competency and personal dimensions of image. Journal of Public Relations Research, 16(1), 93-125. https://doi.org/10.1207/s1532754xjprr1601_4

Ponte, E. B., Carvajal-Trujillo, E., \& Escobar-Rodriguez, T. (2015). Influence of trust and perceived value on the intention to purchase travel online: Integrating the effects of assurance on trust antecedents. Tourism Management, 47, 286302. https://doi.org/10.1016/j.tourman.2014.10.009

Riggio, R. E. (2014). Followership Research: Looking Back and Looking Forward. Journal of Leadership, 13(14). https://doi.org/10.12806/V13/I4/C4

Ryssel, R., Ritter, T., \& Georg Gemunden, H. (2004). The impact of information technology deployment on trust, commitment and value creation in business relationships. Journal of Business \& Industrial Marketing, 19(3), 197207. https://doi.org/10.1108/08858620410531333

Tyler, T. R. (2003). Trust within organisations. Personnel Review, 32(5), 556-568. https://doi.org/10.1108/0048 3480310488333

Ulaga, W., \& Eggert, A. (2006). Relationship value and relationship quality: Broadening the nomological network of business-to-business relationships. European Journal of marketing, 40(3/4), 311-327. https://doi.org/10.1108/030 90560610648075

Valieva, A. B., Orazbaieva, A. M., \& Shaiheslyamova Kazyna, O. (2016). The Image of a Manager in Market Conditions. IEJME-Mathematics Education, 11(7), 1971-1985.

Verhoef, P. C., Franses, P. H., \& Hoekstra, J. C. (2002). The effect of relational constructs on customer referrals and number of services purchased from a multiservice provider: Does age of relationship matter? Journal of the Academy of Marketing Science, 30(3), 202-216. https://doi.org/10.1177/0092070302303002

Xie, Y., \& Peng, S. (2009). How to repair customer trust after negative publicity: The roles of competence, integrity, benevolence, and forgiveness. Psychology \& Marketing, 26(7), 572-589. https://doi.org/10.1002/mar.20289

Zaccaro, S. J., Kemp, C., \& Bader, P. (2004). Leader traits and attributes. The nature of leadership, $101,124$.

Zameer, H., Tara, A., Kausar, U., \& Mohsin, A. (2015). Impact of service quality, corporate image and customer satisfaction towards customers' perceived value in the banking sector in Pakistan. International Journal of Bank Marketing, 33(4), 442-456. https://doi.org/10.1108/IJBM-01-2014-0015

The article has been reviewed.

Received in September 2019; accepted in April 2020. 